\title{
Pharmaceutical Brush Device
}

National Cancer Institute

\section{Source}

National Cancer Institute. Pharmaceutical Brush Device. NCI Thesaurus. Code C149361.

Administration device fitted with a fine brush used for the application of liquid

pharmaceutical forms. 